\title{
Elaboration of Forest Management Aspect in Indonesia 's Forestry Legal Perspective
}

\author{
RORRY PRAMUDYA \\ Lecture School of Law Science Habaring Hurung Sampit, Central Kalimantan
}

\begin{abstract}
ION
RESEARCH law on the Elaboration Aspects of Forest Management in Perspectieve Indonesian Forestry Law is implemented based on the research law methode of normative. From elaboration, it was found that the essentially utan as a gift of God Almighty has various dimensions that are positive. As national development capital has tangible benefits for the life and life of the Indonesian people, both ecological, social, cultural and economic benefits, in a balanced and dynamic way. For that the forest must be protected, managed, utilized, protected and preserved continuously for the welfare of the community, both present and future generations. Ecologically, in position as one determinant of the life support systems, forests have been of great benefit to mankind, therefore, must be preserved. In this connection, forest has a role as a buffer and balancer of the global environment . So closely related to the global and international dimensions becomes very important, while still prioritizing national interests 1 . Forests have a role as a buffer and balancer of the global environment, so that its relationship with the international world becomes very important, while still prioritizing national interests. In the case of forest destruction, the impact is not only threatening the lives of the people of Indonesia, but also the world community and damaging the conditions and accelerating the pace of global warming. Forest destruction and degradation in Indonesia is caused by various things. One of them is due to the legislation governing forestry in all aspects related to denganny a (land, mining, plantation, spatial, environmental, Government authorities and local government and so on are not organized in a legal system that is comprehensive, harmonious and synchronous either vertically or horizontally. Sekaitan with it, overall legal principles forestry incarnated in various forms of legislation and regulations forestry are arranged in a legal system. If not, it will be easy to cause conflict between the rule of law itself.
\end{abstract}

Keywords: Forest Management, Indonesia; Forestry Law

DOI: $10.7176 / \mathrm{JLPG} / 93-04$

Publication date: January $31^{\text {st }} 2020$

\section{I . Background}

Article 12 of Law Number 4 of 1982 concerning Basic Provisions for Environmental Management as perfected by Law No. 19 of 1997 emphasized that the provisions regarding the conservation of living natural resources and their ecosystems were stipulated by law . then published Law No. 5 of 1990 concerning Conservation of Biological Natural Resources and their Ecosystems.

Enforcement of Law No. 23 of 1997 concerning Environmental Management replaces Law No. 4 of 1982, then according to article 9 of Law No. 23 of 1997 has been taken over the formulation of article 12 of Law No. 4 of 1982. Therefore, Law No. 5 of 1990 is still relevant to be maintained and developed.

Article 5 Law No. 5 of 1990 states that the conservation of biological natural resources and their ecosystems is carried out through activities: life support system protection ; preservation of plant and animal species diversity together its ecosystem; sustainable use of living natural resources and their ecosystems. As a gift from God Almighty the forest is a source of natural wealth that is useful and needed by humans. In Indonesia, forest is one of the living natural resources which is the basic capital of national development from many other capital that must be protected and utilized for the welfare of the people in a sustainable manner.

Forest is one of the natural wealth that has many benefits for humans, both in terms of socio-economic, and ecological, attached to it a management mandate, by keeping it from cutting down. This is of course related to hwith generations to come who also have rights over forest potential.

The condition of these forest resources, which is increasingly worrisome, will not improve in the near future. The lack of direction in the implementation of management in the forestry sector since mid-1998 and the worsening of recent times has been a strong incentive to reduce forest areas.

The rate of forest reduction which is now stated to reach $1.6-1.8$ million hectares may increase rapidly in the next five years.[1] This makes the destruction of forests is rising fast, one reason is the system of prevention and control of deforestation is not running according to program and inconsistent, is the result of frequent alternation of institutional leadership in field forestry. ${ }^{1}$

\footnotetext{
${ }^{1}$ https://regional.kompas.com/read/2016/08/30/15362721/every.tahun.hutan.indonesia.hilang.684,000 . hectares . Data in 2016 states that every year, Indonesia loses 684,000 hectares of forest due to illegal logging, forest fires, forest encroachment and forest conversion. According to data released by the Food and Agriculture Organization (FAO) based on data from the Global Forest Resources Assessment (FRA), Indone s he ranks second highest world forest loss after Brazil, which ranks first. In fact, Indonesia is referred to as the megadiverse
} 
Presence of Laws Law No. 41 of 1999 concerning Forestry, Law No.32 of 2004 concerning Regional Government, Law No. 33 of 2004 concerning Financial Balance between the Central Government and the Regional Government, and Government Regulation No. 25 of 2000 concerning the Authority of the Central Government and Provincial Governments as Autonomous Regions.

The four policies were issued to respond to the demands of reform so that they were imbued with a spirit of desealization and a very strong regional autonomy. This can be seen as a new hope for the management of forest resources in the future but also seen as a threat. ${ }^{1}$

\section{Forestry Aspects in the Environmental Dimension}

Law No. 32 Year 2009 concerning potential protective and managemen Environment (UUPLH) confirmed on sustainable development, namely in Article 1 point 3 is defined as a conscious and planned effort that blends the environment, including the resources into the development process to ensure Ability a n, welfare and the quality of life of present and future generations. Therefore the role of the community are expected as defined in Article 7 paragraph (1) UUPLH namely " People have the same opportunity and wide as possible to b e rperan in environmental management". 2

Forest management is basically a form of business activities conducted in ran GKA benefit of forests and forest products according to the regulations by Law 's regulations. Forms of forest management is divided into two parts, the first, the lawyer elolaan state forest that is, a form of business activity conducted government or legal entity referred to in order to obtain the benefits of forests and forest products in the forest area countries, based on the regulations per Law 's that applies to me.

Second, community forest management, that is, a form of business activity carried out by a person or legal entity in the context of obtaining the benefits of forests and forest products, on owned land or other rights, based on the prevailing regulations. ${ }^{3}$

In the development of state forest management, various activities are carried out to obtain and increase forest production and yields in an optimal and sustainable manner. In particular, in the field of forest tenure implemented management activities in the forest area of production which has been set se s uai Forest Land Use Agreement.

Based on Law Number 5 of 1967 concerning Basic Forestry Provisions (UUPK), it was later replaced by Law No. 41 of 1999 which was revised with PERPPU No. 1 of 2004 and Government Regulation Number 21 of 1970 concerning Forest Concession Rights and Forest Product Collection Rights, the exploitation of state forests in Production Forest Zones is carried out by State-Owned Enterprises and or with designated Private Enterprises.

From this principle, it is stated in several decisions of the Minister of Forestry as Community Forestry. The community forest system is actually arranged in good faith, by giving forest resources management to the community, and is sustainable. Onfortunately the system Community Forestry are probably prepared in haste, so that the process of formulation per Law his determination to deny the basic principles of law. Normatively, the rule of law must comply with the principle:

Built with valid logic, refer to the theoretical framework and proven empirical experience, refer to values that are universally acceptable. Forest management basically becomes the authority of the government and / or regional government. Installs gat various regional specialties as well as social and environmental conditions strongly associated with forest conservation and public interest that requires special management capabilities, the implementation of certain region may be delegated to B adan State Owned Enterprises (SOE), which is engaged in forestry. In forest management, then as a national resource forest should be utilized as much as possible for the community that should not be centered on the individual, group, or class necessarily, therefore, uses must be distributed equitably through increased community participation, so that the public is increasingly empowered and developing its potential. ${ }^{4}$

Based on Article 21 of Law No. 41 of 1999 concerning Forestry, forest management includes forest management activities and preparation of forest management plans, forest use, use of forest areas, forest rehabilitation and reclamation, forest protection and nature conservation.

The forest is the mandate of God Almighty, so in its management it must be carried out by giving priority to

country because it has the widest forest with the richest biodiversity in the world

${ }^{1}$ See: Wiyono ,. " Forest Resource Management in the Context of Autonomy" . 2001. AruPA website.

${ }^{2}$ Koesnadi Hardjasoemantrri. 2004. Indonesian Environmental Law. Yogyakarta: Gajah Mada University Press. P.112.

${ }^{3}$ Almar, Idris Sarong. 1993. Conservation of Forests and Legal Aspects (A juridical analysis) Part I . (Upgrading Materials) Jakarta: Ministry of Forestry . P. 23.

${ }^{4}$ See: https://ilmugeografi.com/ilmu-bumi/hutan/p Potential-source-daya-alam-hutan . That the forest is an area where trees and other types of plants grow. Understanding the forest does not just stop that simple. Forests can also be regarded as ecosystems that become a place to live and interact with animals and plants. The forest consists of three main parts, namely the upper part, the surface part of the land and the underground part. In part a forest bag there is a natural canopy that is the leaves of trees that grow moist. On the surface of the forest land there are parches of dried leaves and overgrown with bushes and grass. While at the bottom there is a forest soil nutrients, plant roots, sources springs and is also inhabited by microorganisms. 
the greatest prosperity of the people, therefore it must also pay attention to the cultural values of the community, pay attention to the rights of the people, and therefore must involve the local community. Empowering communities in the management of forest has been expressly stipulated in Law number 41 of 1999 on Forestry in Chapter IX and Chapter X

Management foresty directed at both production forests managed by state-owned enterprises and private parties in principle be implemented based on principles of management and forest protection and sustainable optimal. ${ }^{1}$

In addition to the legal basis of the sustainable forest management derived from national law, sources of international law through the ratified and used as guidelines to strengthen the existence and role of forests for development nation and country. International agreements which are universal policies for forest and environmental conservation partners are mainly aimed at: Guaranteed ecological processes that support the life support system. Maintaining the diversity of genetic resources and types of ecosystems. Controlled sustainable use of biological natural resources.

These global forms of environmental policy can still be harmonized in the interests of conservation of natural resources and their ecosystems.

Law Number 23 of 1997 (LN 1997 No. 68) concerning the Environment mentions this issue in Article 8 which reads: Natural resources are controlled by the state and are used to the greatest extent possible for the prosperity of the people and their arrangements are determined by the government.

To carry out the provisions referred to in paragraph (1) the task of the Government: Regulate and develop policies in the context of environmental management. Regulate the provision, designation, use, management of the environment and the reuse of natural resources, including genetic resources. Regulate legal actions and legal relations between people and / or other legal subjects as well as legal actions against natural resources and artificial resources including genetic resources.

\section{Control activities that have social impacts.}

Develop funding for the conservation of environmental functions according to the rules per Act 's regulations. ${ }^{2}$ The provisions referred to in paragraph (2) shall be regulated further by a Government Regulation. As regulated in Law Number 41 Year 1999 (LN. 167) and PP No. 34 of 2002 concerning Forestry, an example of the Law established at the beginning of the reform era Article 21 paragraph (1) and (2) also regulates the right of control from the State.

All of forest in the territory of the Republic of Indonesia including the natural resources contained therein controlled by the state for the greatest prosperity of the people. State's Forest Control as referred to in paragraph (1) authorizes the Government to: Regulate and manage everything related to forests, forest areas and forest products. Define the status of certain areas as forest areas or forest areas as non-forest areas. Regulate and establish legal relations between people and regulate legal actions regarding forests. ${ }^{3}$

To ensure the optimal and sustainable use of forests for the benefit of the country's development and community welfare, the rules, systems and mechanisms for implementing forest management are established. In this connection, the legal policy management of forest on state forest land ranging solid foothold in the initial implementation of PELITA I, as a follow-up the implementation of the three series of Law , for example:

(a) Law Number 1 of 1967 concerning Foreign Investment

(b) Law Number 5 of 1967 concerning Basic Forestry Provisions

(c) Law Number 6 of 1968 concerning Domestic Investment.

Forest management activities, especially in production forest areas, are carried out based on the Business Work Plan which is prepared and examined by a number of professionals in their respective fields. Those who were involved in the planning process and field survey, derived from various disipli $\mathrm{n}$ science are different from each other.

As empirical data, for example, there is a provision that requires every application for a tourism permit to conduct an Environmental Impact Analysis. In the implementation of AMDAL, a team of personnel is formed who has the educational background of bachelor of world science, economics, biology, law, geology, forestry science and relevant fields of science in a team unity oriented in their respective fields of science, commonly used language / technical term s ulit understand other team members. Meanwhile, it is desired that the final report be integrated in harmony to produce a complete, systematic and accurate report form and content.

\footnotetext{
${ }^{1}$ Forests can be found in father's territory with tropical, lowland and highland climates (read: Types of Forests Based on Climate ). There are a variety of forest types include deciduous forests, forest savannas, forests heterogeneous, homogenous forest, mangrove forests , artificial forests da $n$ rainforest tropics. Indonesia as a country on the equator has tropical rain forests that are always moist throughout the year. Biodiversity in tropical rain forests is very high. This has become a potential natural resource for Indonesia. Potential forest resources can be in the form of wood or non-wood. The following explanation.

${ }^{2}$ Abdurrahman. 2002. Some Legal Aspects of Natural Resource Management. Paper presented at the LPMA event. Banjarmasin. P. 2

${ }^{3}$ Ibid. P. 3.
} 
General policy on nature conservation activities and living costs, is directed at:

(a) the guarantee of ecological processes that support the life support system,

(b) preserving the diversity of genetic resources and the types of ecosystems,

(c) the controlled utilization of living natural resources in a sustainable manner. ${ }^{1}$

The Earth Summit (Summit) which took place from 3-14 June 1992 in Rio De Janeiro, Brazil, produced 5 Convention documents, namely:

(1) Rio Declaration

(2) Agenda 21

(3) Documents concerning Management Principles

(4) Convention on Climate Change

(5) Convention on Biodiversity. ${ }^{2}$

The conference, which involved almost all countries, both developed and developing countries, has managed to reach a consensus on the need for environmental integration into development. Developing countries that are members of the res o Mpok 77 have demonstrated their important role and seek to urge the developed countries to pay attention to the difficulties faced by developing countries. Especially, regarding the sources of funding that are necessary in order cloned partitions and dams environment and sustainable development.

Regarding forestry issues, especially the interests of developing countries, especially Indonesia itself has basically been anticipated by stating the need for 27 international decisions to be carried out first then an arrangement can be made in the future.

The formulation is desired and requested by developed countries with the implementation which is binding on developing countries from the results of the convention.

The Rio Declaration contains 27 principles $^{3}$ relating to environmental issues and global development. The important objective of the principles contained in it is to form a new and balanced global partnership by creating a new and close level of cooperation between countries, important sectors of society and all people in general. The principles of the declaration also covers the environment and development issues related to the state and development yan $\mathrm{g}$ related to the circumstances and needs of developing countries that need attention.

In this connection, a collaboration between every nation and country is needed to eliminate poverty which is the main condition for realizing sustainable development. In relation to the issue of the international economy, the principle of the need to create an open system that supports economic growth and sustainable development in all countries is stated. Actions field trade considering the environmental aspects of discrimination should not be carried out or used as barriers to international trade activities. Other principles contained in the declaration are aimed at efforts to provide a basis for the preparation of various international agreements that respect the interests of each party and protect the integrity of the global environmental and development system.

Action program agenda 21 , is a work in the field of environment and development that contains a comprehensive action program and is aimed at reorganizing human activities in tackling environmental damage and ensuring a sustainable development process. The program consists of 40 chapters with more than 100 programs a rea described in the basics of action, objectives, activities and ways of implementation, including financing and cost evaluation. There are 8 issues that have been identified as difficulties in negotiations, namely sources of funding, technology transfer, principles on forest management, atmospheric protection, biodiversity ( biodiversit / biotecnology ), clean water sources, institutions and legal instruments.

The principles of forest management, containing 16 principles related to agreed forestry issues . Called the document " Non Legally Binding Authoritative Statement of Principles for Global Consensus and Sustainable Development of all types of forests. The principles in the document contain guidelines that are not binding and apply to all types of forests. Other principles include wood trade, eliminating tariff barriers and improving market access. In addition, it was agreed on the agenda 21 regarding deforestation include: function of forests, enhancement of forest protection, conservation and forest utilization, efficiency of use and assessment of the value of forest products and services, and the increased capacity planning monitoring and evaluation.

Climate change conventions, there are several principles, among others: the need for commitment, especially developed countries to immediately limit greenhouse gas (GHG) emissions and help develop greenhouse precipitation. To that end, it is necessary stabilization of greenhouse gas concentrations in the atmosphere at a level yan $\mathrm{g}$ does not harm the world's climate system. It is the responsibility of developed countries to anticipate climate change and help developing countries that are vulnerable to climate change.

Convention on biological diversity, there beb erapa important principles are: to preserve and utilize sustainably biodiversity, the state has the sovereign right to exploit natural resources and their responsibility to

\footnotetext{
${ }^{1}$ See Law No. 5 of 1990 concerning Conservation of Biological Natural Resources and their Ecosystem.

${ }^{2}$ Koesnadi Hardjasoemantri. Op.cit . Pages 20-32.

${ }^{3}$ https://www.hukumonline.com/berita/baca/lt58db11bbd773f/kenali-deklarasi-rio-yang-dirujuk-hakim-lingkungan/ . See reference to a judge in deciding environmental issue. For example: Haksim uses the precautionary principle contained in the 1992 Rio Declaration as a basis for punishing five defendants in a joint responsibility to pay compensation to the plaintiff (residents of Kadungora Subdistrict, Garut).
} 
not damage the environment, intensification and analysis used to control the damage to biodiversity. This convention regulates, among other things:

(a) in conservation, namely: preservation of ecosystems and natural habitats and maintenance and restoration of certain species ;

(b) Existing conservation, namely the preservation of components of biological diversity outside their natural habitat.

(c) Sustainable use of biodiversity.

\section{III.Forest Qualifications in the Perspective of Environmental Conservation}

In the environment in Indonesia, there are many problems related to the environment, one of which is forest pollution. Forests can also suffer damage if their utilization is not controlled well . Forests are a renewable natural resource. One example of pollution or forest destruction is illegal logging. If the activity is carried out continuously, it can result in deforestation forest. ${ }^{2}$

On a broader dimension, it is realized that the declining quality of the environment has threatened the survival of human life and other living things. For this reason, it is necessary to protect and manage the environment properly managed. All parties must be aware of the fundamental problems relating to the environment. For that all components of society has the right obligation and which together to preserve the environment. All people have the same right to get a good and healthy environment. ${ }^{3}$

Problems which are based on the attention of environmental issues are only formally triggered as a result of the United Nations Conference on the Environment in Stockholm on June 5, 1972. From this, the establishment of June 5 each year as a world environmental day. It will always be repeated as a momentum to be concerned about environmental conditions that are increasingly degraded in quality, while intending to repair, or at least inhibit the damage.

The Stockholm conflict is a form of concern over the condition of the world environment which is getting degraded and the quality has even reached an alarming stage. As an added measure was agreed Agenda 21 in Rio de Janeiro in 1992 and Conf e Rensi-environment conference in subsequent years, which is routinely and scheduled implemented in various countries (West) in turn.

That this reflects the concerns of the global community on environmental issues. For the same reason, the various meetings showed a commitment to improve the environment, or at least inhibit the rate of damage. Various studies on repair and what to do continues to be discussed and it all requires good will, kh bowels of government of the participating countries to follow up.

In relation to environmental problems in Indonesia, these environmental issues have been recorded since the 1960s. Beginning of concrete measures from environmental management is when conducted seminar on Environmental Management and Development, held at Padjadjaran University on 15-18 May 1972. In this forum, elaborated problems related with the environment in all its dimensions.

Normatively, the seminar gave birth to Law No. 23 of 1997 concerning Environmental Management. Although there is a slanted voice that the birth of the Act was not due to international pressure, but objectively Indonesia does need legal instruments to regulate environmental problems. With advancing developments, the rule of law must also be updated in accordance with future developments.

Finally, it was passed Law No. 32 of 2009 concerning Environmental Protection and Management (UUPPLH) which is idealized as a normative tool for guidelines in the management and protection of the environment in a more structured sense of management that is more directed, both in planning, implementing and monitoring various modes of violation of environmental law life.

Advances in technology that is growing rapidly now makes us forget the importance of the environment. Human's life can not be separated from their environment. Both the natural environment and social environment. We breathe need air from the surrounding environment. Eating, drinking, keeping healthy, everything involves the environment. That is why we forget the importance of awareness of protecting the environment and preserving it. Especially the forest environment, forests as the lungs of the world that produce oxygen for life.

Environmental problems arise as a result of human activity itself, from day to day the threat to environmental damage is increasing. The number of new land clearing resulted in many forests ravaged for general land clearing te $r$ call does not follow the rules of ecology. Destruction of the forest will damage the ecosystems in the forest and around the forest and damage all living systems in every component on this earth. Preserving forests means saving all the components to live, maintained forest will provide a good water management in the downstream area so it will save all the activities in general and in particular economic

\footnotetext{
${ }^{1}$ See: https://thegorbalsla.com/hiversity-hayati/. That ecosystem diversity is one of the most important things on earth. It is used as a function of climate, an indicator for us to know that there is a change in ecosystems and ecological systems. It can also be used as one aspect that influences the development and stability and community of an organism.

${ }^{2} \mathrm{https} / / /$ www.scribd.com/doc/25139330/makalah-environment-life

${ }^{3}$ Samsul Wahidin, 2014. Legal Dimensions of Environmental Protection and Management. Yogyakarta: Learning Library. Thing. 12 .
} 
activity, in addition to the best-maintained forest will provide enormous benefits for the environment, forests as the lungs the lungs of the world will reduce global warming, reduce drought in summer and reduce the risk of landslides and floods during the rainy season. ${ }^{1}$

Forest preservation is to maintain the sustainability of the ecosystem components. Conservation is a process of maintaining ecosystems, managing biological and environmental diversity, education, and integrated conflict resolution in a particular area .

Forestry Aspects as the Basis for Creating a Good Environment

Forest is an area that is overgrown with thick trees and other plants. Such areas exist in large areas of the world and function as carbon dioxide sinks, animal habitats, hydrological current modulators, and soil conservation, and are one of the most important aspects of the earth's biosphere. ${ }^{2}$

Forests are a form of life that is spread throughout the world. We can find forests in both the tropics and cold climates, in the lowlands and in the mountains, on small islands and on large continents. Forests are a collection of plants and plants, especially trees or other woody plants, which occupy a large enough area.

The tree itself is a tall plant with many years of life. So, of course it's different from vegetables or grains that live only one season. The tree also differ as markedly have a piece of upright woody enough staple length and shape of the canopy (crown leaves) which clearens. A collection of trees considered to be forest if creating a climate and environmental conditions of local specialties, different daripad a region beyond. If we are in a tropical rain forest, it feels like getting into a warm, damp sauna room, which is different from the surrounding farming area. The scene is different. This means that all the other plants and animals (higuns smallest), as well as various other inanimate elements including parts of an integral constituent of the forest.

Forest as an ecosystem does not only store natural resources in the form of wood, but there are still many non-timber potentials that can be utilized by the community through the cultivation of agricultural crops on forest land. As a function of the forest ecosystem is important in a variety of things such as a water source, producing oxygen, the lives of millions of flora and fauna, and the role of counterweight environment and prevent global warming. As a function of providing water for forest life is one of the most important areas, this is because the forest is a place where millions of plants grow. ${ }^{3}$

So, forests are a form of life that develops with a very distinctive, complex, and dynamic. In the end, the way all forest compilers adjust to each other will produce a climax form, which is a form of plant and animal society that is most suitable to the available environmental conditions. As a result, we see forests in various forms of climax, for example: savanna forests, deciduous forests, tropical rain forests, etc. ${ }^{4}$

Miscellaneous kind of forest; Foresters try to classify forests according to their individual appearance. The aim is to make it easier for humans to recognize the unique nature of the forest. By recognizing the true nature of a forest, we will treat forests more precisely so that forests can be sustainable, even growing.

The term forest derived from seeds, shoots, and a mixture of seeds and shoots. Forests derived from seeds are also called ' high forests ' because trees that grow from seeds tend to be taller and can reach a later age. Forests originating from shoots are called ' low forests ' for the opposite reason.

Mixed forests are, therefore, called ' medium forests '. Other classifications by origin are: Virgin forest (primary) is forest that is still original and has never been cleared by humans. Secondary forest is forest that grows back naturally after being cut down or extensive damage. As a result, trees in secondary forests often appear shorter and smaller. But if left uninterrupted for a long time, it will be difficult to distinguish secondary forests from primary forests. Under appropriate conditions, the secondary forest will be able to recover to forest primary after hundreds of years old.

According to the way of rejuvenation (regrowth); Forests can be distinguished as forests with natural regeneration, artificial regeneration, and mixed regeneration. Forest with natural regeneration means that tree flowers are pollinated and tree seeds are spread not by humans, but by wind, water or animals. Forests with artificial regeneration mean humans intentionally pollinate flowers and spread seeds to regrow forests. Forest with mixed regeneration means a mixture of the two previous species .

In temperate zones, flowering occurs in a short time, often does not take place every year, and more pollination through the wind. In the tropics, flowering occurs almost throughout the year and almost every year. As an exception, the flowering of dipterocarp (meranti) trees in Kalimantan and Sumatra occurs periodically. In certain years, meranti forests bloom together, but in later years Meranti did not flower at all. Season flower of meranti wood is a golden opportunity to see the seeds of meranti has a pair of wings hovering in the wind.

According to the type of arrangemen; Based on the arrangement of its types, we recognize similar forests and mixed forests. Similar forests, or pure forests, have trees that are mostly of one type, although this does not mean that there is only one type. A kind of forest can grow naturally well as climate and soil characteristics that

\footnotetext{
${ }^{1}$ Ibid. P. 23.

${ }^{2}$ https://id.wikipedia.org/wiki/Hutan

${ }^{3} \mathrm{http}: / /$ wartawarga.gunadarma.ac.id/2010/01/kerusak-hutan-indonesia/

${ }^{4} \mathrm{http}$ ://informasi-kehforest.blogspot.co.id/tentang-hutan.html
} 
are difficult or because of certain tree species leb i h aggressive. For example, pine forests in Aceh and Kerinci were formed because extensive forest fires have occurred and only tree species survive. Forests can also be a kind of artificial forest, which is only one or a few types of po h on the main planted like that by humans, such as is done in lands HTI (plantation forest).

Other classification based on species arrangement is coniferous forest and broad leaf forest. Needle forests (such as pine forests ) are generally found in cold climates, while broad-leaf forests (such as meranti forests) are common in the tropics.

According to age, In this connection forests can be distinguished as age forest (approximately the same age) and forest not age. Natural forest or natural forest forest is usually not a forest age. Plantations may be age forests or non-age forests.

Based on its geographical location

a. tropical forests, i.e. forests in the equator.

b. temperate forests, forests in four seasons (between latitudes $23.5^{\circ}-66^{\circ}$ ).

c. boreal forest, forests in the polar ring.

d. based on the Seasonal Properties

e. rainforest (rainforest), with many rainy seasons .

f. evergreen forest.

g. forest season or deciduous forest (deciduous forest).

h. savannah forest, in places with long dry seasons. Etc.

i. jungle tour.

j. based on the height of the place

k. forest beach (beach forest)

1. lowland forest

m. sub-mountain forest

n. mountain forest

o. mist forest

p. elfin forest (alpine forest)

q. based on the state of the land:

r. freshwater swamp forest or freshwater swamp forest

s. peat swamp forest

t. mangrove swamp forest, or mangrove forest

u. heath forest

v. limestone e forest, and others

w. based on the dominant tree species:

x. teak forest (teak forest), for example in East Java.

y. pine forest (pine forest), in Aceh.

z. dipterocarp forests (dipterocarp forest), in Sumatra and Kalimantan.

aa. eucalyptu $\mathrm{s}$ forest in Nusa Tenggara. Etc.

Based on the properties of manufacture:

1. natural forest

2. man-made forest, for example:

3. community forest

4. urban forest

5. forest planting an industry (timber or timber plantation estates) Etc. based on the management objectives

a. production forest, which is managed to produce timber or non-timber forest product

b. protected forest, managed to protect land and water systems

c. nature reserve forest, managed to protect the richness of biodiversity or natural beauty

d. conversion forests, i.e. forests that are reserved for other uses, can be converted for non-forestry management.

e. In fact, often some of the distinguishing factors combine, and develop unique forest characteristics. For example, lowland tropical rainforest (lowland tropical rainforest), or dipterocarp forest (hilly dipterocarp forest). Community forests, ker a $\mathrm{p}$ constructed in the form of a mixture of forestry plants with short-term agricultural crops, so termed agroforestry or Agroforest.

Types of Forests in Indonesia

1) Based on Biogeography

Nusantara Islands is a natural relief formed by the process of meeting between three earth plates. To this day, the three plates of the earth are still approaching each other. As a result, among other things, earthquakes often occur in this island country. 
The history of the formation of the archipelago in the equatorial belt produces three main biogeographic areas, namely: Sundanese Exposure, Wallacea, and Sahul Exposure. Each biogeographic region is a reflection of the spread of life forms based on the differencesurface physical their ground.

Sundanese Exposure Region (in the west)

Sunda Exposure is a plate of earth that moves from the Oriental Region (Asian Continent) and is on the west side of the Wallace Line. The Wallace Line is an imaginary boundary line between the world of flora and fauna in the Sunda Exposure and in the eastern part of Indonesia. This line moves from north to south, between Kalimantan and Sulawesi, and between Bali and Lombok. This line follows the names of the biologist Alfred Russel Wallace who, in 1858, showed that pe $\mathrm{r}$ distribution of flora and fauna in Sumatra, Kalimantan, Java, and Bali is more similar to that on the mainland continent of Asia.

Sahul Exposure Region (in the eastern part); Sahul Exposure is an earth plate that moves from the Australesia Region (Australian Continent) and is on the east side of the Weber Line. The Weber Line is an imaginary boundary line between the flora and fauna world in the Sahul Exposure and in the more western part of Indonesia. This line stretches from north to south between the Maluku Islands and Papua and between East Nusa Tenggara and Australia. This line follows the name of the biologist Max Weber who, around 1902, showed that the distribution of flora and fauna in this region was more similar to that of the Australian Continent.

Wallace / Deep Sea Region (in the middle); The East Asian edge of the earth plate is moving between the Wallace Line and the Weber Line. This area includes Sulawesi, the Lesser Sunda Islands (Nusa Tenggara), and the Maluku Islands. Flora and fauna in this area is a lot of endemic species (found only in place I arms, not found in any other part of the world).

However, this region also has elements both from the Oriental Region and from the Australesia Region. Wallace argued that the sea was covered in ice during the Ice Age so plants and animals in Asia and Australia could cross and gather in the archipelago. Although the types of flora and fauna in Asia remained more numerous in the western part of the Australian fauna and flora in the eastern part, this is because the area was once a sea trench Wallace ya $\mathrm{n} g$ is so deep that it is difficult to pass through the fauna and flora stopped spreading.

2) Based on climate

From its latitude, Indonesia is indeed a tropical region. However, its position between two continents and between two oceans makes the island's climate more diverse. Based on the comparison of the number of dry months to the number of wet months per year, Indonesia covers three climate regions, namely:

The area type climate A (very wet) which is the peak season of rain fell between October and January, sometimes until February. This area includes Sumatra Island; Kalimantan; the western and central parts of Java; west side of Sulawesi Island.

B type climate regions (wet) which peak in the rainy season falls between May and July, and August or September as the driest month. This area covers the eastern part of Sulawesi Island; Maluku; most of Papua.

Climate type $\mathrm{C}$ (slightly dry) regions have less rainfall, while the driest months are longer. This area includes East Java; parts of Madura Island; Bali Island; Nusa Tenggara; the southernmost tip of Papua.

Based on these climate differences, Indonesia has peat forests, tropical rain forests and monsoon forests ;

a) Peat forests exist in climate type A or B regions, namely on the east coast of Sumatra, along the coast and large rivers of Kalimantan, and most of the southern coast of Papua.

b) Tropical rain forests occupy areas of climate types A and B. These forest types cover most of the islands of Sumatra, Kalimantan, Sulawesi, North Maluku, and Papua. In the western part of Indonesia, the highest forest canopy is filled with the dipterocarpaceae family (mainly the genera Shorea, Dipterocarpus, dryobalanops, and Hopea). The canopy underneath is occupied by the family Lauraceae, Myristicaceae, Myrtaceae, and Guttiferaceae. In the east, the main genera are Pometia, Instia, Palaquium, Parinari, Agathis, and Kalappia.

c) Monsoon forests grow in C or D climate type areas, namely in Central Java Yogyakarta, East Java, Bali, NTB, parts of NTT, parts of southeast Maluku, and parts of the southern coast of Irian Jaya. Tree species in this forest such as teak (Tectona grandis), walikukun (Actinophora fragrans), eucalyptus ( Eucalyptus alba), sandalwood ( Sant alum album ), and kayu putih ( Melaleuca leucadendron ).

3) Based on the nature of the soil

Based on the nature of the land, forest types in Indonesia include coastal forests, mangrove forests, and swamp forests.

a) Coastal forests are found along dry, sandy, and non-sloping beaches, such as on the south coast of Java. Tree species such as ketapang (Terminalia catappa), hibiscus (Hibiscus tiliaceus), sea fir (Casuarina equisetifolia), and pandan (Pandanus tectorius).

b) Forest mangrove Indonesia reached 776,000 ha and scattered along the north coast of Java, Sumatra's east coast, along the coast of Borneo, and the southern coast of Papua. The main tree species belong to the genus Avicennia, Sonneratia, and Rhizopheria. 
c) Forest bogs are found in almost all the islands, especially Sumatra, Kalimantan, and Papua. Swamp tree species for example are nyatoh (Palaquium leiocarpum), kempas (Koompassia spp), and ramin (Gonystylus spp).

4) Based on land use

The area of Indonesia's forests has continued to shrink, as the following table shows: Forest Area Determination Area by the Ministry of Forestry Year 1950 Hectares 162.0 million 1992118.7 million 2003110.0 million 2005 93.92 million. Based on results of the interpretation of satellite imagery, Huta district $n$ Indonesia reached 93.92 million hectares in 2005, it can be specified utilization as follows:

a) Permanent forest: 88.27 million ha

b) Conservation forest: 15.37 million ha

c) Protection forest: 22.10 million ha

d) Limited production forest: 18.18 million ha

e) Huta $n$ fixed production: 20.62 million ha

f) Convertable production forests: 10.69 million ha.

g) Other Use Areas (non-forest areas): 7.96 million ha.

The largest forest area is in Papua (32.36 million ha), followed by Kalimantan (28.23 million ha), Sumatra (14.65 million ha), Sulawesi (8.87 million ha), Maluku and North Maluku (4.02 million ha), Java (3.09 million ha), and Bali and Nusa Tenggara (2.7 million ha).

\section{IV . Elaboration of Meaning of Forests in Legislation Regulations}

Sometimes legal subjects are confused with the notion of forests related to the names of forests in Indonesia. At first glance it looks like an overlap, for example between protected forest and conservation forest, or a nature conservation area and a nature reserve area. Yet it is not so, Negar a set about forestry in different forest-related regulations. ${ }^{1}$

The definition of forest as explained in Law No. 41 of 1999 concerning forestry is: " An ecosystem unit in the form of a vast expanse of biological natural resources dominated by trees in their natural environment, which cannot be separated from one another."

There are 4 laws relating to forestry directly, including:

1. Law Number 41 of 1999 concerning Forestry.

2. Law Number 5 of 1990 concerning Conservation of Biological Natural Resources and their Ecosystems.

3. Law Number 19 of 2004 concerning the Establishment of Government Regulations in lieu of

4. Law Number 1 of 2004 concerning Amendments

5. Law Number 41 of 1999 concerning Forestry Becoming

6. Law Number 18 of 2013 concerning Prevention and Eradication of Forest Destruction.

In general, the state views forests from two aspects, namely their status and function. Status refers to the status of forest ownership. In terms of status can be known ownership of a forest area. While the function of the forest sees the forest from its benefits and role for life. The function of these forests are more related to how a forest is managed.

In this connection, previously, only two types of forest ownership status were recognized in Indonesia, namely state forests and private forests. State forest refers to forests whose status is owned by the state and forest rights are forests that are owned by individuals or legal entities.

Later, indigenous groups challenged the provision that said customary forests were included in state forests. They demanded the existence of customary forests by submitting a judicial review of Law No.41 of 1999 to the Constitutional Court.

The Constitutional Court granted the community's demands as reflected in the Constitutional Court Decision No. 35 / PUU-X / 2012. One of the contents of the ruling changed the notion of customary forest, from being originally referred to as " state forest within the territory of indigenous peoples" to " forest within the territory of indigenous peoples", the word " state" was abolished. On that basis three concepts of forest are now known based on their status, viz ${ }^{2}$ :

\section{State Forest}

State forest is forest that is on land that is not encumbered with land rights. This state forest is owned by the state. All forms of control and management must be authorized by the state.

\section{Forest rights}

Forest rights of the forest that are on land subject to land rights, in terms of the Act keh utanan formerly called

\footnotetext{
${ }^{1} \mathrm{https}: / /$ wisatahutan.wordpress.com/

${ }^{2}$ htt ps: //ensiklopedia.id/hutan.html
} 
forests. Ownership of this right forest can be in the hands of individuals or legal entities.

\section{Customary forest}

Customary forests are forests that are in the area of customary law communities. As of this writing there has been no detailed explanation of what is meant by customary law communities, whether individuals, legal entities or community groups.

In another perspective, that forest has an important function for life. The existence and continuity of forests needs to be safeguarded by all elements of the community. On that basis, it needs a good arrangement in utilizing and managing it. The following understanding of forests is seen from their functions.

a. Protected forest

Protection forest is a forest whose existence is protected to maintain its function as a buffer for the life system . Protect an area from the dangers of flooding, drought, landslides and other ecological disasters. For example to protect the function of watersheds, an area is designated as protected forest. Technically location can kawasa $\mathrm{n}$ production forests or other places. As long as its existence is considered important to maintain environmental balance, the area can be designated as protected forest.

b. Conservation forest

Conservation forests are forests that are reserved for the preservation of biodiversity and their ecosystems. Conservation forests are divided into two groups, namely nature reserves and nature conservation areas. Both of these notions of forest have the same function of preserving the diversity of animals, plants and their ecosystems. It's just that in the area of nature conservation is followed by the word sustainable use of these resources.

The nature reserve area, its main function is to preserve the diversity of plants, animals and their ecosystems. A nature reserve is a forest area that is protected because it has biodiversity and has a unique ecosystem that grows naturally. Usually the nature reserve area is not too broad. A wildlife reserve is a forest area that is protected because it is a unique animal habitat or has a high diversity of animals.

The nature conservation area, its main function is to preserve the diversity of plants, animals and their ecosystems. These natural resources can be used sustainably. A national park is a large forest area intended for biodiversity preservation and nature protection. This area has complete functions, including other types of conservation forest functions. Usually divided into several zones, including the core zone, the zone of use and zo $\mathrm{n}$ a-zone other specifically regulated.

Grand forest park is a forest area that is intended for biodiversity preservation and nature protection. The trees and animals in it can be native or imported from outside the area. Its function is rip with botanical gardens. Nature tourism park is a forest that is intended for tourism and nature recreation activities.

The hunting park is a forest which besides having a conservation function is also intended to accommodate hobbies or hunting activities. Understanding this forest may not be so familiar in the community. In terms of quantity and extent it is not as large as other types of forests. Although in other countries that have a tradition of hunting recreation, hunting parks become a mainstay of foreign exchange in the sector to achieve of tourism.

c. Production forest

Production forests are forests that can be exploited for production exploitation, both timber and non-timber production. There are various types of production forests such as HPH, HTI and other types. In another perspective, that of forest conservation in an environmental perspective it's ecara etymology of the word, the word is derived from the preservation of the word " sustainable" that has lasting meaning, unchanging, eternal, in accordance with the circumstances as they are. If the word sustainable is related to the environment, it means that the environment must not change, it must be lasting and must be in accordance with the original conditions or remain in the original state. ${ }^{1}$

Preservation of environmental functions is defined as a series of efforts to maintain the continuity of the carrying capacity and carrying capacity of the environment. Carrying capacity of the environment is the ability of the environment to support the lives of humans and other living things. Preservation carrying environment's life is a series of efforts to protect the environment's ability to pressure changes and / or negative impact caused by an activity in order to remain able to support humans and other living creatures. Capacity environment life is the ability of the environment to absorb substances, energy and / or other components into or incorporated into it. Preservation of environmental carrying capacity is a series of efforts to protect the ability of the environment to me $\mathrm{n}$ yerap substances, energy and / or other components are discharged into it (Article 1, point 5,6,7,8,9 UUPLH)

Forest is an ecosystem unit in the form of a stretch of land containing biological natural resources which is dominated by trees in natural environment which cannot be separated from one another. Forestry is a management system that has to do with forests, forest areas and forest products that is held in an integrated manner. The forest area is designated a particular region and / or set o leh Government to be protected as

\footnotetext{
${ }^{1} \mathrm{http}: / /$ sharingilmupajak.blogspot.co.id//pelestari-fungsi-hut an-and-environment.html
} 
permanent forest. The forest products are objects of biological, non-biological and derivatives as well as services from forests (Article 1 point a, b, c, k, and m, Chapter I of the General Provisions of Law No. 41 of 1999 by Forestry, hereinafter referred to as UUK.

The environment is a unity of space with all objects, power, conditions and living things, including humans and their behavior that affect the continuity of life and welfare of humans and other living things. To guarantee the preservation of environmental functions, every business and / or activity is prohibited from violating quality standards and standard criteria for environmental damage. Every business plan and / or activity that is likely to cause a large and significant impact on the environment, must have an Environmental Impact Assessment abbreviated to AMDAL (Article 1 point 1, Article 14 paragraph 1 and Article 15 paragraph 1, Chapter I concerning General Provisions and Chapter V concerning Preservation of Environmental Functions of the UUPLH).

Preservation of the ability of forest functions and environmental functions that are harmonious and balanced" leads to the qualification between " development" and forest functions and environmental functions ", so that the two notions are confronted with one another. As for the "preservation of forests and environmental functions" which means preserving the functions of forests and environmental functions that are used in order sich forest conservation areas, natural resources environment and nature reserves.

Development in various aspects of life and life aims and has the meaning to make a change, building is changing something to achieve the improvement and better achievements. If the development process $\mathrm{i}$ tu occurred unfavorable impact on the function of forests and environmental functions, he must do the effort to eliminate or reduce the negative impact that the state of forests and environmental functions into a harmonious and seimb a ng again. Thus, what is conserved is not "the environment an sich" , but "the ability of the environment". Environmental capacity in a harmonious and balanced is what needs to be preserved so that any changes that are held always $\mathrm{d} i$ accompanied by efforts to achieve harmony and balance of the environment on a new level,

Attention to the preservation of forest functions was followed up by the international community and UN organizations occurred at the UN Earth Summit held in Rio de Janeiro, Brazil on June 3-14, 1992. This conference was called the United Nations Conference on Environment and Development which was abbreviated by UNCED attended by 177 heads of state and government representatives who gatheer round in Rio de Janeiro and was attended also by representatives of the UN environmental agencies and other institutions.

This conference has given rise to a consensus agreement document called the Conservation and Sustainable Development of all Types of Forrest (Forrestry Principles). Consensus This agreement makes forest principles and is an international consensus that consists of 16 chapters that cover aspects of the management, conservation aspects and aspects of the utilization and development, is not $\mathrm{m}$ engikat legally and applies to all types of forests.

In the Preamble Forrestry Principles the content of forestry principles is stated as follows: ${ }^{2}$

1. forestry issues related to the overall range of environmental and development problems and opportunities including the right to sustainable socio-economic development.

2. the purpose of the directives of these principles is to provide shares in the management, conservation and sustainable development of forests and to ensure their diverse and complementary functions and uses.

3. forestry issues and opportunities should dili hat with a holistic and balanced manner within the overall context of environment and development by considering the function and use of forests are diverse, including the use of traditional, and social and economic pressures that may arise if utilization inhibited or restricted, as well as the potential for development that sustainable forest management can provide.

4. these principles reflect the first global consensus on forests. In giving their commitments to implement these principles appropriately, countries also decide to always make an assessment of these principles whether it is still adequate in connection with the development of international cooperation on forest issues.

5. This principle applies to all types of forests, both natural forests and plantations in all geographical areas and climate zones, including austral, boreal, sub-temperate and temperate, sub-tropical and tropical forests.

6. all types of forests embody prose-process ecologically complex and unique that is the basis for current capacity and potential capacity to provide resources to satisfy human needs and environmental values, and thus the management and conservation of the $t$ epat is of interest for the government of countries that have these forests and have value for the local community and for the environment as a whole.

7. Forests are essential for economic development and maintenance of all forms of life.

8. recognizes that the responsibility for forest management, conservation and sustainable development in many countries is allocated between the levels of the federal / national, state / provincial and local governments, so that each country in accordance with the constitution and / or national law must follow the principles this principle at the appropriate level of government.

\footnotetext{
${ }^{1}$ Ibid.

${ }^{2}$ https: // ag uraforestry.com // understanding- forest-and-principles- forest sustainability/
} 
In Indonesia the main attention to the problem of preserving forest functions and environmental functions is regulated in the National Medium-Term Development Plan (RPJM) established on January 19, 2005 in RI Presidential Regulation No.7 of 2005 concerning the National Medium-Term Development Plan of 2004- 2009 Presidential Decree regulates the provision of management 1 ingkungan life laid down in Chapter 32 on Improving the Management of Natural Resources and Environment Preservation Function. In the Presidential Regulation the following main issues are raised:

a. continued decline in the condition of Indonesia's forests.

b. damage to watersheds.

c. coastal and marine ecosystem habitats are increasingly damaged.

d. the image of mining that is environmentally friendly.

e. high threat to biodiversity (biodiversity).

f. damage of water is increasing.

g. air quality, especially in big cities has declined.

h. sustainable forest management systems have not been optimally implemented.

i. the division of authority and responsibility for forest management is not clear.

j. Weak law enforcement (law enforcement) against illegal logging and wood smuggling activities.

$\mathrm{k}$. low forest management capacity.

1. the undeveloped use of non-timber forest products and environmental services.

$\mathrm{m}$. sea borders with neighboring countries have not yet been resolved .

n. marine potential has not been utilized optimally.

o. the spread of fish theft and fishing patterns that damage the environment.

p. management of small islands is not optimal.

q. nuanced mitigation systems have not yet been developed.

r. legal uncertainty in the mining sector.

s. high level of pollution and the implementation of integrated and systematic waste management.

t. policy adaptation to climate change (global change ) and global warming (global warming) has not been implemented.

u. alternative environmental funding has not yet been developed.

v. Global environmental issues have not been addressed and applied in national and regional development.

w. yet harmonious regulation per Act Unda ng an environment.

$\mathrm{x}$. the low awareness of the community in preserving the environment (Chapter 32 concerning Improvement of Natural Resource Management and Preservation of Environmental Functions, Presidential Regulation No. 7 of 2005 concerning National RPJM, 2014-2019).

Management of forest functions and environmental functions is based on the preservation of a harmonious and balanced environmental capacity to support sustainable development for improving human welfare. The definition of preservation implies the achievement of a harmonious and balanced function of the forest and environmental functions and the enhancement of these capabilities. Only in a harmonious and balanced environment can optimal life be achieved.

\section{CLOSING}

That in essentially utan as a gift of God Almighty has various dimensions that are positive. As national development capital has tangible benefits for the life and life of the Indonesian people, both ecological, social, cultural and economic benefits, in a balanced and dynamic way. For this reason, forests must be protected, managed, utilized, protected and conserved continuously for the welfare of the community, both current and future generations.

Ecologically, in position as one determinant of the life support systems, forests have been of great benefit to mankind, therefore, must be preserved. In this connection, forest has a role as a buffer and balancer of the global environment. So closely related to the global and international dimensions becomes very important, while still prioritizing national interests 1 . Forests have a role as a buffer and balancer of the global environment, so that its relationship with the international world becomes very important, while still prioritizing national interests.

In the case of forest destruction, the impact is not only threatening the lives of the people of Indonesia, but also the world community and damaging the conditions and accelerating the pace of global warming. Forest destruction and degradation in Indonesia is caused by various things. One of them is due to the legislation governing forestry in all aspects related to with it (land, mining, plantation, spatial, environmental, Government authorities and local government and so on are not organized in a legal system that is comprehensive, harmonious and synchronous both vertically and horizontally.

Relation with it, overall legal principles forestry incarnated in various forms of forestry laws and regulations are arranged in a legal system. If not, it will easily lead to conflict between the rules of law itself. 


\section{REFERENCES}

Ali Akbar. 1999. Safeguarding the Wisdom of Lukal Indigenous Peoples . Pontianak: Dayak Society Study Institute.

Almar, Idris Sarong. 1993. Conservation of Forests and Legal Aspects (A juridical analysis) Part I . (Upgrading Materials) Jakarta: Ministry of Forestry.

J. Kusni. 2000. Lessons From Dayak Communities. Pontianak: Institute of Dayakology.

Koesnadi Hardjasoemantri. 2000. Environmental Law an . Issue 7. Yogyakarta: Gadjah Mada University Press.

Lampah D. Sihite. 2000. Biodiversity in Indonesia. Pontianak: Dayak Community Study Institute,

Sarbaini. 1999. The Socio-Cultural Approach of Indigenous Peoples Welcomes a United Indonesia. Solo: Panepen Mukti.

Suwiryo Ismail, 1999. " Strengthening the Role of Communities in the Management of Natural Resources and the Environment in the Regions" Paper Presented at the Training on Preparation of the Environmental Impact Management Program in collaboration with ProLH-BAPEDAL, Jakarta Dec. 1999

Sukamdani. 1988. Indigenous Peoples in the Legal Anthropology Perspective. Jakarta: Indonesian University.

Wiyono ,. " Management of Forest Resources in the Context of Regional Autonomy " . 2001. AruPA website.

Wahidin, Samsul . Legal Dimensions of Environmental Protection and Management . Yogyakarta: Learning Library.

\section{Internet}

https://regional.kompas.com/read/2016/08/30/15362721/setiap.tahun.hutan.indonesia.hilang.684.000 . hectares . https://ilmugeografi.com/ilmu-bumi/hutan/p potential-sumber-daya-alam-hutan .

https://www.hukumonline.com/berita/baca/lt58db11bbd773f/kenali-declaration-rio-yang-dirdir-hakim-

lingkungan/

https://thegorbalsla.com/ biodiversity- biological / .

https: // id. wikipedia.org/wiki/Forest

http://wartawarga.gunadarma.ac.id/2010/01/kerusak-hutan-indonesia/

http://informasi-kehforest.blogspot.co.id/tentang-hutan.html

https://wisatahutan.wordpress.com/

https://ensiklopedia.id/hutan.html

http://sharingilmupajak.blogspot.co.id//pelestari-fungsi-hutan-dan-lingkungan.html

https://aguraforestry.com// understanding-forests-and-principles-sustainability-forests/ 